\title{
EKSPLORASI POTENSI FISIK KAWASAN PANTAI JOGAN, PANTAI NGLAMBOR DAN PANTAI SIUNG SEBAGAI KAWASAN WISATA PANTAI
}

\author{
Tendi Eko Saputro, Qomarun \\ Program Studi Teknik Arsitektur, Fakultas Teknik, Universitas Muhammadiyah Surakarta \\ Jl. A. Yani Tromol Pos 1 Pabelan Kartasura Sukoharjo 57102 Telp 0271-717417 \\ E-mail: Tendy.diarmahesta@gmail.com
}

\begin{abstract}
ABSTRAK
Latar belakang penelitian ini adalah untuk mencari wahana baru wisata pantai di wilayah Yogyakarta yang telah ditetapkan sebagai wilayah KSPN (Kawasan Strategis Pariwisata Nasional). Tujuan utama riset ini adalah untuk menggali potensi dan kelayakan investasi objek wisata pantai yang baru, yaitu pada Pantai Jogan, Pantai Nglambor dan Pantai Siung. Penelitian ini menggunakan metode kualitatif dengan model pendekatan SWOT (Strength Weakness Opportunity Threat). Pengumpulan data dilakukan dengan survei lapangan, wawancara dan kajian pustaka. Analisis ETOP (Element Threat Opportunity Profile) dan SAP (Strategic Advantage Profile) dilakukan untuk memecahkan permasalahannya. Hasil kajian ini memperlihatkan bahwa ketiga pantai itu mempunyai potensi yang berbeda-beda dan layak untuk dikembangkan menjadi wahana wisata pantai baru di Yogyakarta. Penelitian ini akhirnya merekomendasikan untuk dilakukan tahap penyusunan konsep dan desain arsitektur kawasan pantai. Pantai Jogan mempunyai karakter yang unik, yaitu adanya aliran air yang mengalir dari tebing karang yang langsung jatuh ke bibir pantai, sehingga sering disebut sebagai pantai air terjun. Pantai Nglambor mempunyai pemandangan yang sangat indah, yaitu adanya hamparan pasir putih, pulau karang dan keragaman ikan hias. Sementara itu, Pantai Siung memnpunyai batuan karang yang unik, tebing yang tinggi dan hamparan pasir putih yang luas, sehingga sering disebut sebagai pantai petualang.
\end{abstract}

Kata Kunci: wisata pantai, siung, nglambor, jogan

\section{PENDAHULUAN}

Berdasarkan RIP Kepariwisataan Nasional 2010-2025, Indonesia adalah negara kepulauan, sehingga mempunyai banyak potensi wisata bahari. Dari Sabang hingga Merauke, potensi wisata bahari itu ternyata belum banyak digali. Oleh karenanya, perlu sekali dilakukan penemuan dan pengembangan potensi wisata bahari yang baru. Namun demikian, penemuan daerah wisata yang baru juga harus dikaitkan dengan strategi nasional tentang wisata, seperti kebijakan KSPN (Kawasan Strategis Pariwisata Nasional), supaya lebih efisien dan efektif. Daerah Istimewa Yogyakarta (DIY) sebagai salah satu dari 88 wilayah KSPN di Indonesia (PP No. 50/2011), perlu diketemukan dan dikembangkan lagi alternatif wisata baru, termasuk wisata bahari. Untuk memperjelas peta KSPN tersebut, maka berikut ini digambarkan 88 lokasi sebagai wilayah KSPN dan sekaligus posisi potensi wisata bahari di DIY (lihat Gambar 1).

Secara geografis, dari Gunung Kidul Provinsi DIY sampai dengan wilayah Trenggalek Provinsi Jawa Timur, terdapat rangkaian pegunungan yang berhadapan langsung dengan Samudera Hindia. Oleh karena itu, pantai-pantai di Kabupaten Gunung Kidul terjadi penggabungan wilayah pegunungan dengan pantai (Bapeda Gunung Kidul, 2011). Penemuan dan pengembangan potensi wisata pantai di daerah ini menjadi layak dilakukan demi peningkatan pendapatan asli daerah maupun devisa nasional. Untuk studi ini, maka akan dikaji potensi wisata pantai di beberapa lokasi daerah Kabupaten, Gunung Kidul, DIY, yaitu Pantai Jogan, Pantai Nglambor dan Pantai Siung. Tujuan dari penelitian ini adalah untuk mengidentifikasi 
potensi fisik dan permasalahan yang terdapat di kawasan pantai tersebut. Manfaat dari kajian ini adalah untuk bahan kerangka acuan kerja pembuatan konsep perencanaan dan perancangan arsitektur.

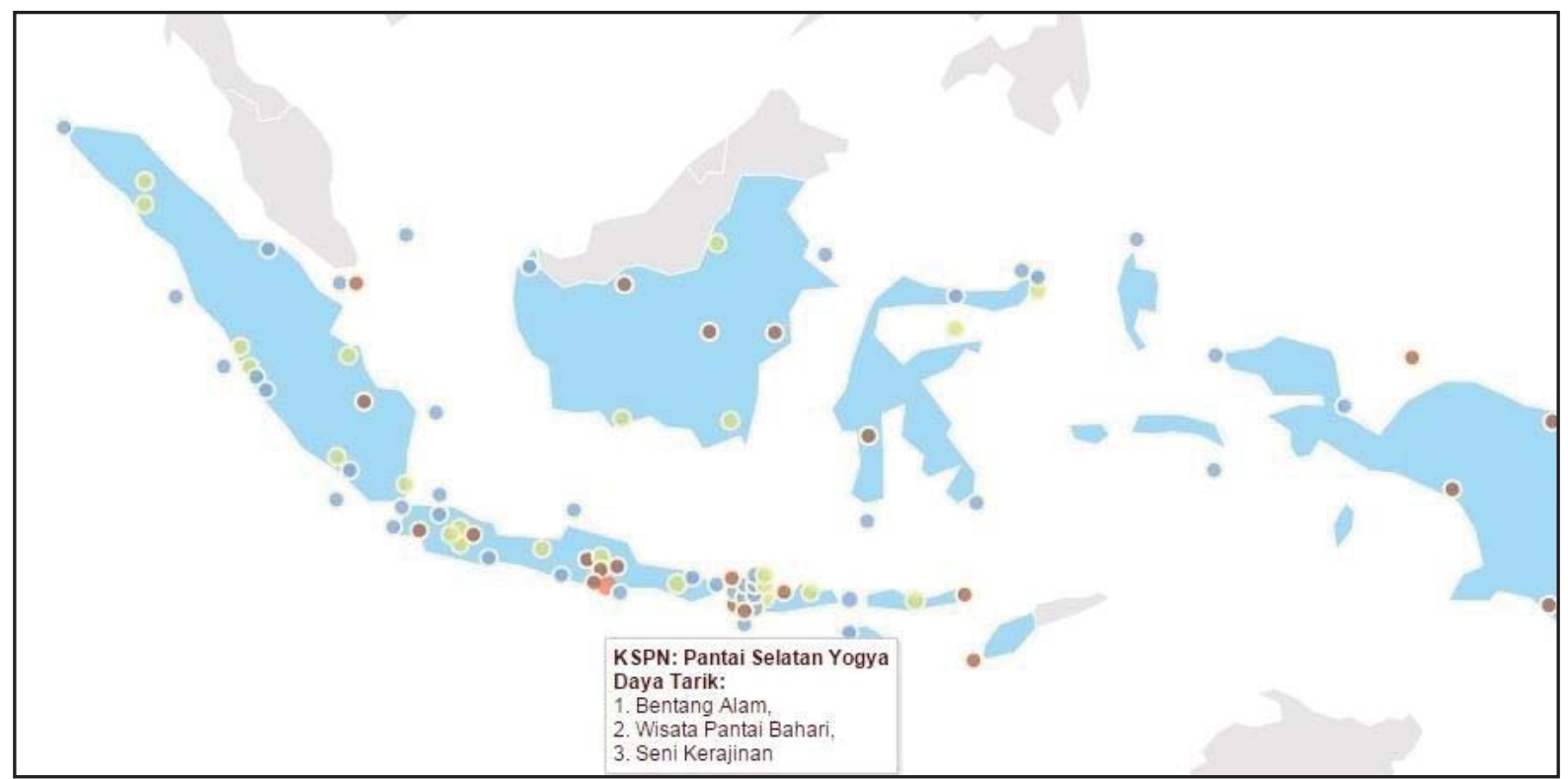

Gambar 1. Peta 88 Lokasi KSPN dan Posisi Potensi Wisata Bahari di DIY (Sumber: PP No. 50/2011)

\section{TINJAUAN PUSTAKA Pantai}

Menurut Ginting (2004), pantai adalah wilayah yang menjadi batas antara daratan dan lautan. Bentuk-bentuk pantai berbedabeda karena terjadi proses yang beragam, seperti pengikisan, pengangkutan dan pengendapan oleh adanya gelombang, arus dan angin yang berlangsung secara terusmenerus. Pesisir adalah wilayah antara batas tertinggi saat air laut pasang hingga batas terendah saat air laut surut. Pesisir, yang sangat dipengaruhi oleh gelombang air laut, merupakan zona yang menjadi tempat pengendapan hasil pengikisan air laut. Manfaat pantai terutama di daerah tropis pada umumnya adalah untuk (Dahuri, 1996): (1) areal tambak garam; (2) daerah pertanian pasang surut; (3) wilayah perkebunan kelapa dan pisang; (4) objek pariwisata; (5) daerah pengembangan industri kerajinan rakyat bercorak khas daerah pantai; dan (6) sumber kehidapan bagi penduduk kawasan pesisir.

Dalam suatu objek wisata (Yoeti, 1985), khususnya wisata pantai biasanya ada unsur yang ditonjolkan sebagai unsur penawaran dan sebagai daya tarik pengunjung. Unsur itu juga yang dijadikan sebagai potensi objek wisata itu sendiri. Adapun unsur penawaran dalam suatu objek wisata itu terdiri dari dua hal, yaitu unsur alami dan unsur non-alami. Unsur alami ini merupakan kondisi ketertarikan karena suatu proses alam atau pengaruh alamiah, sedangkan non-alami merupakan kondisi ketertarikan karena manusia ikut campur di dalamnya.

Pada objek wisata pantai, dimana air sebagai unsur utama dalam semua aktifitas maupun fasilitas yang ada semua berorientasi pada air (water oriented). Kegiatan dalam wisata pantai di kategorikan sebagai berikut: (1) rekreasi alam, meliputi duduk santai, jalanjalan, berjemur dan bermain; (2) olahraga rekreatif, meliputi berenang, memancing, dayung, jet sky, surfing, olagraga penyelaman motor boat dan sepeda air; dan (3) rekreasi seni budaya, berupa seni tradisional, pentas musik dan pameran seni kerajinan setempat.

\section{Wisata}

Menurut UU No. 10/2009, wisata adalah kegiatan perjalanan yang dilakukan oleh seseorang atau sekelompok orang dengan mengunjungi tempat tertentu untuk tujuan rekreasi, pengembangan pribadi, atau mempelajari keunikan dalam jangka waktu 
tertentu. Kawasan pariwisata merupakan kawasan yang disediakan untuk memenuhi kebutuhan kegiatan pariwisata dengan kriteria pemanfaatan ruang: (1) rekreasi alam, meliputi duduk santai, jalan-jalan, berjemur dan bermain; (2) tersedia aksesibilitas yang tinggi ke pusat pelayanan niaga dan kesehatan; (3) memiliki obyek dan daya tarik wisata; (4) pemberlakuan lebar garis sempadan pantai; (5) pengaturan pemakaian air tanah yang disesuaikan dengan kapasitas ketersediaan air tanah dan waktu yang dibutuhkan untuk pengisian kembali; dan (6) lebar garis sempadan pantai 100-300 meter dari titik pasang tertinggi.

Sementara itu, menurut PP No. 50/2011, daerah tujuan wisata atau destinasi wisata adalah tempat atau daerah yang karena keadaan alamnya, atraksi-atraksi budayanya, situasi dalam hubungan lalu-lintas beserta fasilitas kepariwisataannya, menyebabkan daerah tersebut menjadi objek kebutuhan wisatawan. Hal yang menarik wisatawan untuk berkunjung ke suatu tempat adalah benda-benda yang tersedia di alam semesta, seperti: iklim; hutan; flora-fauna; pusat kesehatan; dan hasil ciptaan manusia, seperti sejarah dan kebudayaan. Kawasan Strategis Pariwisata Nasional yang selanjutnya disingkat KSPN adalah kawasan yang memiliki fungsi utama pariwisata atau memiliki potensi untuk pengembangan pariwisata nasional yang mempunyai pengaruh penting dalam satu atau lebih aspek, seperti pertumbuhan ekonomi, sosial dan budaya, pemberdayaan sumber daya alam, daya dukung lingkungan hidup, serta pertahanan dan keamanan.

Pariwisata adalah suatu perjalanan yang dilakukan untuk sementara waktu yang diselenggarakan dari suatu tempat ke tempat yang lain, untuk bertamasya, berekreasi atau memenuhi keinginan yang bermacam-macam. Sementara itu, wisatawan adalah seseorang atau kelompok yang mengadakan perjalanan dengan tujuan berkunjung ke suatu tempat dengan maksud berlibur, berekreasi, dan berolah raga dan lain-lain dalam jangka waktu sedikitnya 24 jam. Fungsi-fungsi kepariwisataan dibedakan menjadi beberapa kategori, yaitu: (1) fungsi sosial, mengenal adat istiadat, kebiasaan, kebudayaan dan aspirasi masing-masing daerah, maka akan timbul rasa cinta tanah air dan bangsa; (2) fungsi politik, menciptakan faktor stabilitas bidang politik, keamanan, ekonomi, sosial dan budaya; (3) fungsi ekonomi, memberikan pendapatan ekonomi dari segi devisa dan pajak; dan (4) fungsi budaya, unsur budaya sebagai modal dasar obyek wisatawan, sebagai pendorong bagi perkembangan kebudayaan itu sendiri. Sementara itu, manfaat langsung dari pariwisata adalah: (1) dari segi ekonomi, menambah pendapatan negara dan merangsang pertumbuhan sektorsektor lain; (2) memperluas pergaulan hidup dan pengetahuan; (3) mendorong perkembangan, penggalian dan pelestarian seni budaya; (4) pariwisata turut menunjang politik negara; (5) pemeliharaan dan pemanfaatan lingku-ngan hidup; (6) memperluas kesempatan kerja; dan (7) menunjang perbaikan keseha-tan dan prestasi kerja. Fasilitas tempat wisata yang harus dipenuhi untuk meningkatkan kenyamanan pengunjung antara lain: (1) sarana transportasi dan komunikasi; (2) sarana pengunjung, seperti hotel, restoran, kesenian tradisional, suvenir dan industri kerajinan, bumi perkemahan, rumah bilyard, diskotik, klub malam, gedung pertemuan dan bioskop.

\section{METODE PENELITIAN}

Metode penelitian yang digunakan dalam kajian ini secara umum adalah metode kualitatif, dalam artian banyak menggunakan pendekatan deskriptif daripada numerik. Tahap-tahap utama dalam penelitian induktif ini adalah sebagai berikut: (1) observasi; (2) literatur; (3) analisis SWOT; (4) pembahasan; dan (5) kesimpulan. Analisis menggunakan metode deskriptif komparatif, menggambarkan kondisi faktual dengan mengemukakan faktafakta yang ada di lapangan serta membandingkannya antara suatu kondisi dengan literatur yang ada. Analisis SWOT mengidentifikasi kekuatan (Strength), kelemahan (Weakness), peluang (Opportunity) dan ancaman (Threat).

Tahap kompilasi data dilakukan melalui observasi, wawancara dan studi literatur, sehingga akan menghasilkan sifat-sifat umum dan khusus dari ketiga pantai yang dikaji. Selanjutnya, data-data yang ada diteruskan kepada tahap analisis data. Tahap analisis SWOT (Qomarun, 1997) dimulai dengan identifikasi elemen ancaman (ETE Environmental Threat Element) dan elemen 
peluang (EOE- Environmental Opportunity Element) pada ketiga pantai yang dikaji, yaitu Pantai Jogan, Pantai Nglambor dan Pantai Siung. Tahap ini akan menghasilkan profil eksternal (ETOP-Environmental Threat and Opportunity Profile) pada wilayah yang dikaji. Profil eksternal ETOP ini akan menghasilkan 4 kemungkinan, yaitu: (1) usaha dewasa; (2) usaha gawat; (3) usaha ideal; dan (4) usaha spekulatif. Kondisi kemungkinan ini biasa disebut sebagai matrik ETOP, yang merupakan perpaduan antara ETE dan EOE. Selanjutnya, masing-masing wilayah yang dikaji itu akan dianalisis lagi berdasarkan profil internalnya (SAP-Strategic Advantage Profile). Berbeda dengan analisis ETOP, pada analisis SAP akan menghasilkan 5 kemungkinan, yaitu: (1) posisi persaingan lemah; (2) posisi persaingan bertahan; (3) posisi persaingan aman; (4) posisi persaingan kuat; dan (5) posisi persaingan unggul. Selanjutnya, analisis SWOT diakhiri dengan 2 kemungkinan hasil, yaitu investasi atau divestasi. Hal ini tergantung pada perpaduan antara ETOP dan SAP di atas. Jadi, analisis SWOT (Porter, 1980) pada akhirnya harus menghasilkan kesimpulan yang tegas, yaitu investasi atau divestasi, bukan sekedar deskripsi saja.

\section{PEMBAHASAN}

Hasil kajian ini memperlihatkan bahwa ketiga pantai mempunyai potensi yang berbeda-beda dan layak untuk dikembangkan menjadi wahana wisata pantai baru (investasi) di Yogyakarta. Pantai Jogan mempunyai karakter adanya aliran air dari tebing karang, sehingga sering disebut sebagai pantai air terjun. Pantai Nglambor mempunyai pemandangan pasir putih yang sangat indah, sedangkan Pantai Siung mempunyai batuan karang dan tebing yang tinggi, sehingga sering disebut sebagai pantai petualang. Adapun temuan kondisi dan potensi masingmasing pantai dapat dijelaskan sebagai berikut:

\section{Temuan Kondisi Interface}

Secara garis besar, kondisi interface di Pantai Jogan adalah sebagai berikut: (a) mempunyai pasir yang sedikit; (b) mempunyai ombak dan batuan karang; (c) mempunyai batuan karang dan air terjun yang jatuh langsung ke bibir pantai; dan (d) mempunyai potensi sunset. Sementara itu, kondisi interface Pantai Nglambor adalah sebagai berikut: (a) mempunyai 2 pulau di dekat pantai; (b) mempunyai hamparan pasir putih dan batuan karang dan ombak yang relatif sedang; (c) mempunyai ombak dan batuan karang; dan (d) mempunyai kondisi pantai yang diapit tebing sehingga ombak relatif sedang dan bisa digunakan sebagai lokasi snorkeling. Selanjutnya, kondisi interface Pantai Siung adalah sebagai berikut: (a) mempunyai hamparan pasir putih yang luas; (b) mempunyai kondisi ombak sedang; (c) mempunyai bukit karang yang tinggi; dan (d) mempunyai tebing yang yang tinggi dan permukaan yang unik sehingga dapat digunakan untuk olahraga rock climbing.

\section{Temuan Kondisi Ombak}

Pada lokasi penelitian Pantai Jogan, maka terdapat ombak yang cukup tinggi dengan kisaran 2-3 meter. Keadaan ini dikarenakan langsung menghadap ke Samudra Hindia arah Selatan dan Barat Daya. Pantai Jogan yang sebelah Barat juga terdapat deburan ombak yang langsung menghatam ke arah dinding tebing (tebing corong), sehinga terdengar seperti suara gemuruh dan warna ombak yang berada di atas batuan-batuan karang sangat indah. Sementara itu, pada lokasi penelitian Pantai Nglambor, yang terdapat tiga pulau (yaitu Pulau Watulombor, Pulau Watupanjang dan Pulau Watupayung), maka ombak cenderung lemah dengan kisaran 1-1,5 meter. Ketiga pulau itu menghalangi ombak yang datang dari Selatan, sehingga ombak menjadi melemah. Pada lokasi ini sangat berpotensi sebagai lokasi area snorkling. Selanjutnya, pada lokasi Pantai Siung, maka ombak juga diketemukan cukup tinggi dengan kisaran 2-3 meter, karena posisi langsung menghadap ke Samudra Hindia.

\section{Temuan Kondisi Vegetasi}

Karena ketiga lokasi penelitian berdekatan, maka jenis vegetasi yang ada di Pantai Jogan, Pantai Nglambor dan Pantai Siung tidak jauh berbeda.

\section{Temuan Kondisi Pasir}

Keadaan pasir di lokasi penelitian Pantai Jogan, Pantai Nglambor dan Pantai Siung adalah Pasir putih. Namun demikian, masingmasing pantai mempunyai perbedaan terkait 
luasan dan fisiknya. Untuk Pantai Jogan, luasan pasir putih hanya sedikit, sedangkan Pantai Nglambor dan Pantai Siung mempunyai hamparan pasir putih sangat indah. Kondisi pasir putih di kedua pantai itu terlihat alami dan bersih, karena masih belum banyak orang tahu.

\section{Temuan Kondisi Karang}

Seperti umumnya pantai yang berada di kawasan Gunung Kidul dan Pegunungan Seribu, maka dominasi karang batuan kapur adalah daya tarik tersendiri. Bahkan, karang ini telah menjadi andalan wisata alam selama beberapa dekade.

\section{Temuan Kondisi Sunset dan Sunrise}

Sunset dan sunrise merupakan hal yang sangat penting, dalam unsur penawaran wisata pantai. Namun demikian, di ketiga kawasan penelitian ini hanya bisa melihat sunset dan sunrise di titik-titik tertentu saja.

\section{Temuan Kondisi Perahu}

Secara tidak langsung, keberadaan perahu akan semakin menarik minat wisatawan. Namun demikian, dari ketiga lokasi penelitian hanya Pantai Siung yang terdapat perahu. Kapal perahu dari kayu ini belum dikomersialkan, melainkan hanya digunakan para nelayan setempat.untuk mencari ikan .

\section{Temuan Kondisi Pasang-Surut}

Di kawasan lokasi penelitian Pantai Jogan, Pantai Nglambor dan Pantai Siung terdapat jenis pasang surut tunggal, yaitu keadaan dimana terjadi pasang surut terjadi 1 kali dalam sehari. Keadaan pasang terjadi pada sore hari, kurang lebih mulai pukul 4 sore, sedangkan keadaan surut terjadi pada pagi hari, kurang lebih pukul 5 pagi.

\section{Temuan Kondisi Perairan}

Secara umum, kondisi perairan pada Pantai Jogan, Pantai Nglambor dan Pantai Siung masih sangat bersih, karena jauh dari pencemaran lingkungan dan masih sedikitnya pengunjung yang datang.

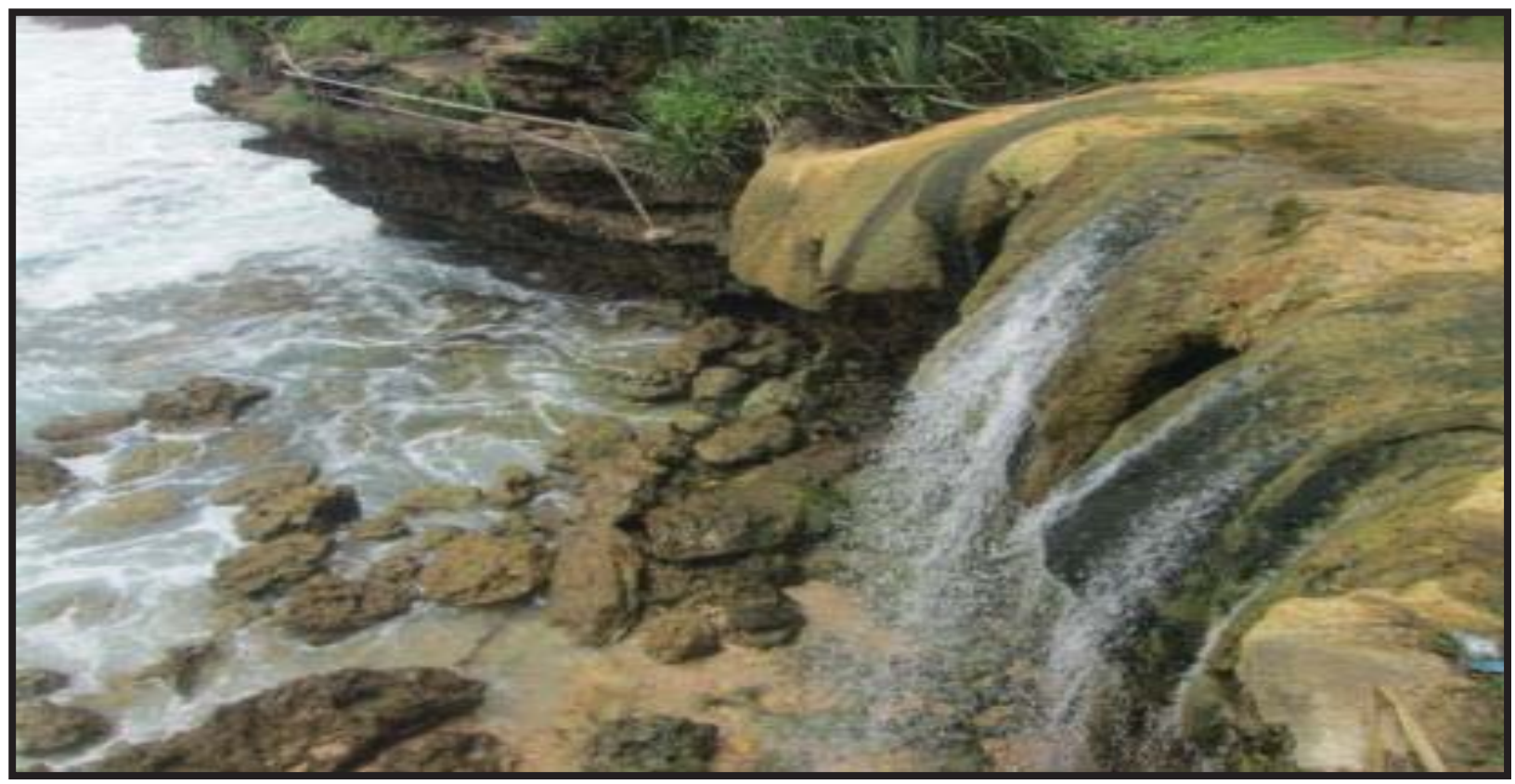

Gambar 2. Kondisi Pantai Jogan Sumber : Survei 2013 


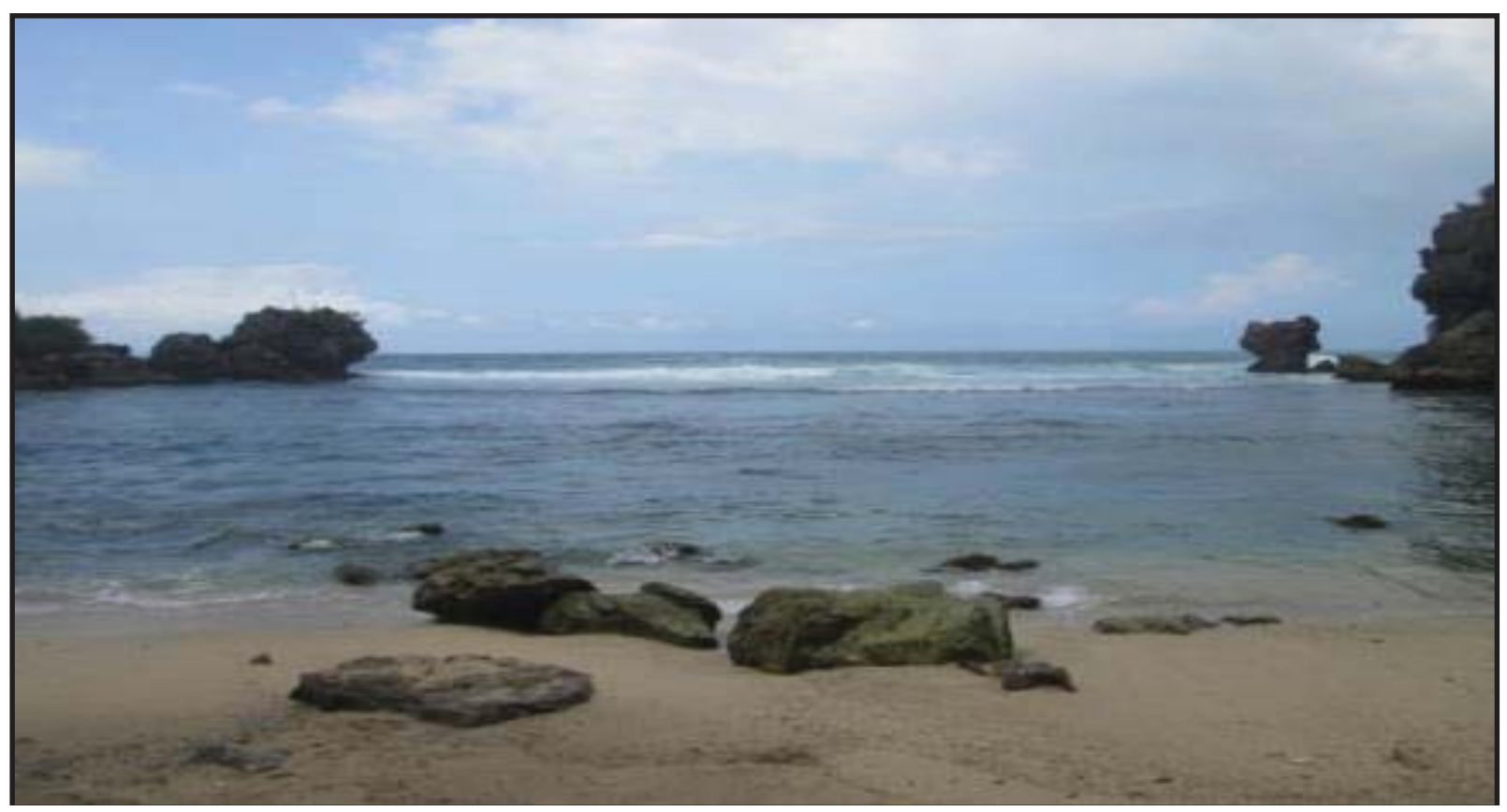

Gambar 3. Kondisi Pantai Nglambor Sumber : Survei 2013

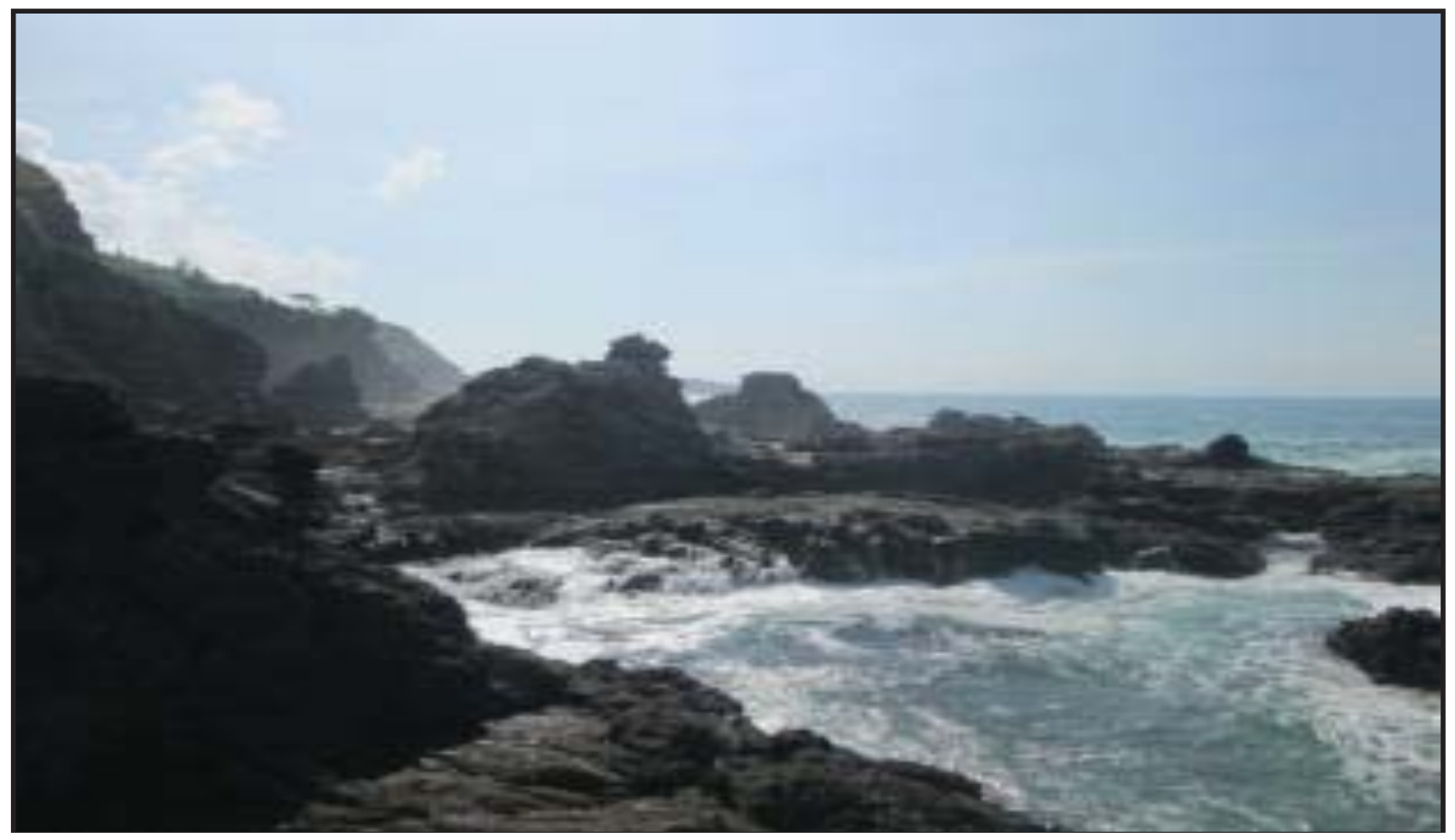

Gambar 4. Kondisi Pantai Siung

Sumber : Survei 2013

I Tendi Eko Saputro.. Oomarun.. Eksplorasi potensi fisik kawasan pantai iogan. pantai nalambor dan pantai 
Tabel 1. Matrik Analisis SWOT Pantai Jogan

\begin{tabular}{|c|c|c|}
\hline $\begin{array}{c}\text { Analisa SWOT } \\
\text { Pantai Jogan }\end{array}$ & 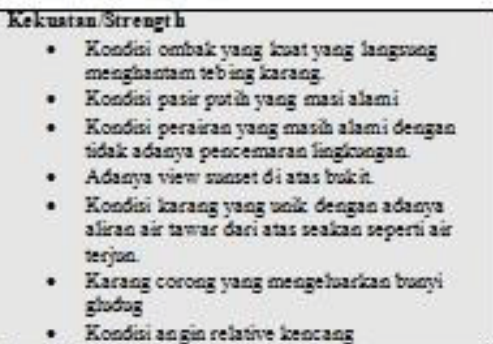 & 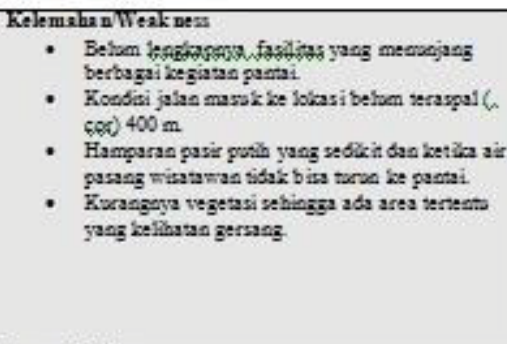 \\
\hline 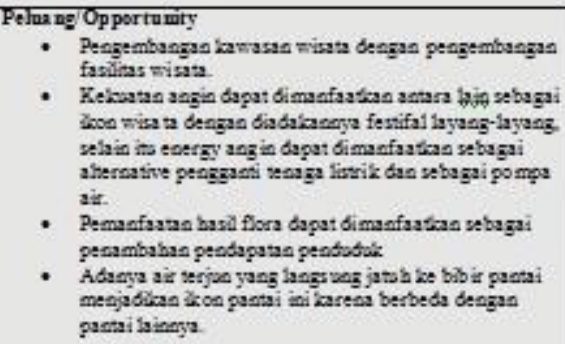 & 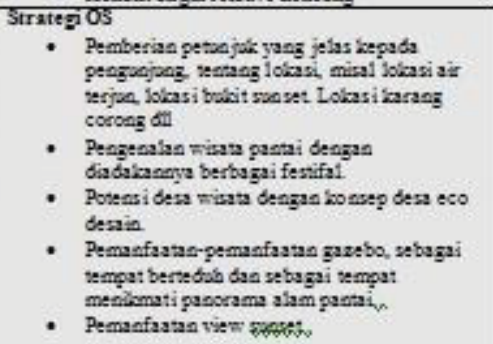 & $\begin{array}{l}\text { Strategi OW } \\
\text { - Pembangaan berbagi fasulitas wisata }\end{array}$ \\
\hline 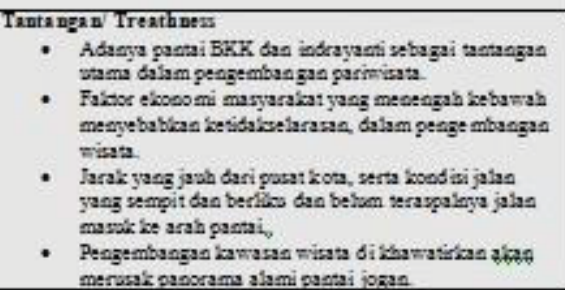 & 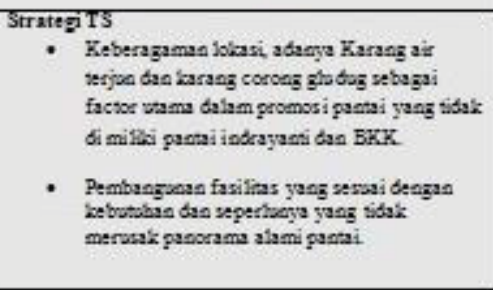 & 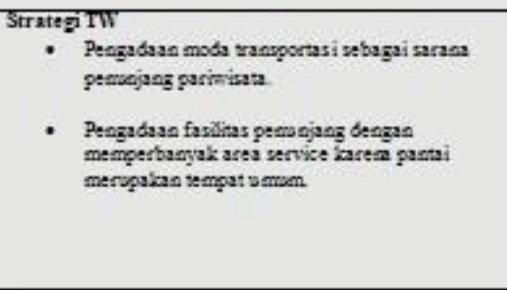 \\
\hline
\end{tabular}

(Sumber: Analisis, 2013)

Tabel 2. Matrik Analisis SWOT Pantai Nglambor

\begin{tabular}{|c|c|c|}
\hline $\begin{array}{c}\text { Analisa SWOT } \\
\text { Pantai Nglambor }\end{array}$ & 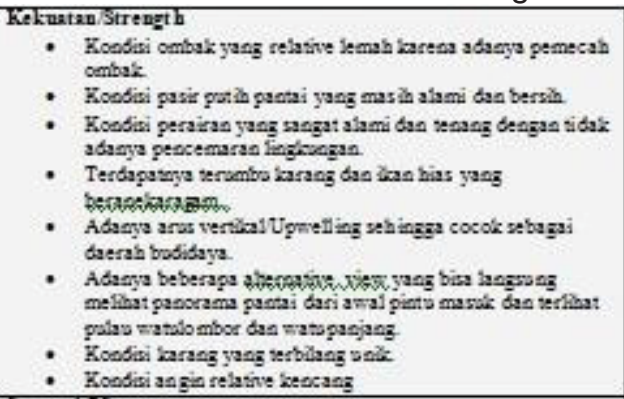 & 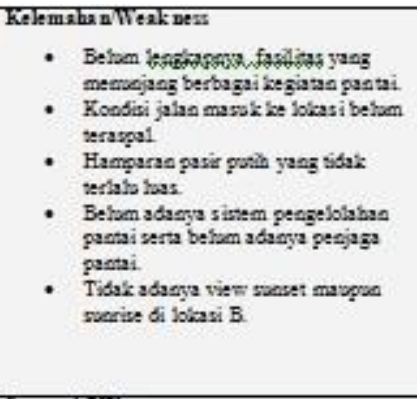 \\
\hline 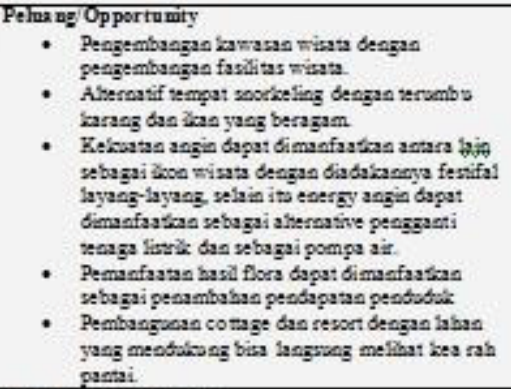 & 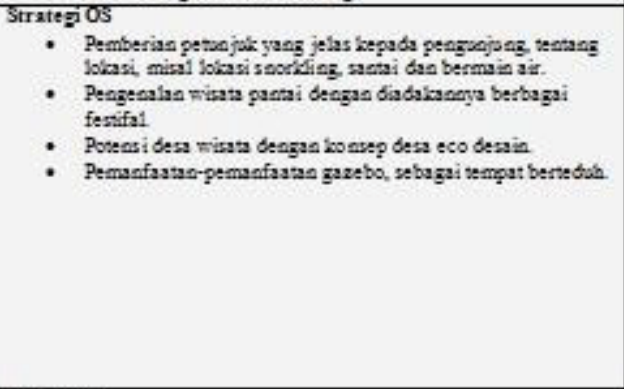 & 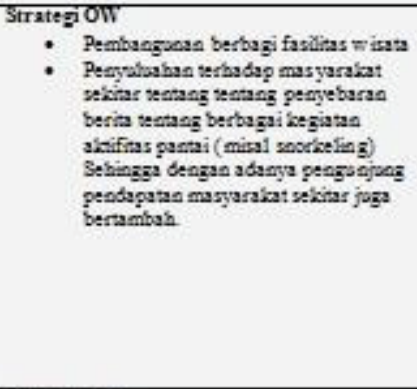 \\
\hline 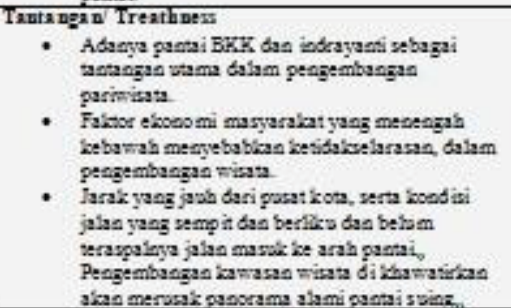 & 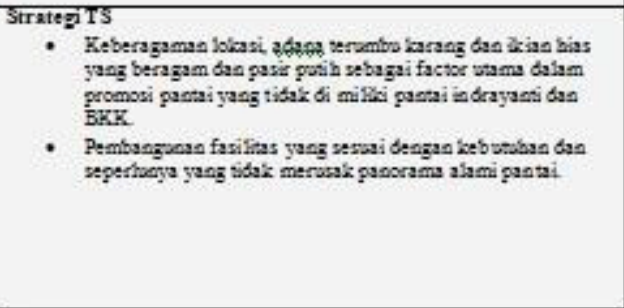 & 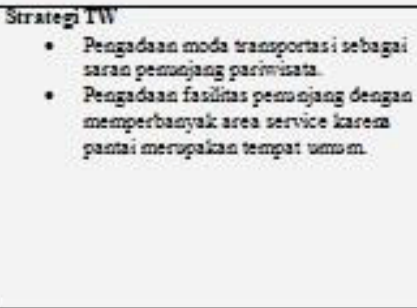 \\
\hline
\end{tabular}

(Sumber: Analisis, 2013) 
Tabel 3. Matrik Analisis SWOT Pantai Siung

\begin{tabular}{|c|c|c|}
\hline $\begin{array}{c}\text { Analisa SWOT } \\
\text { Pantai Siung }\end{array}$ & 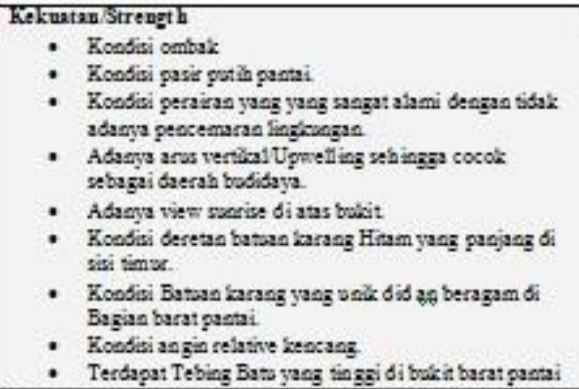 & 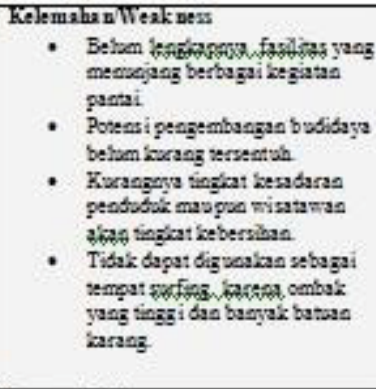 \\
\hline 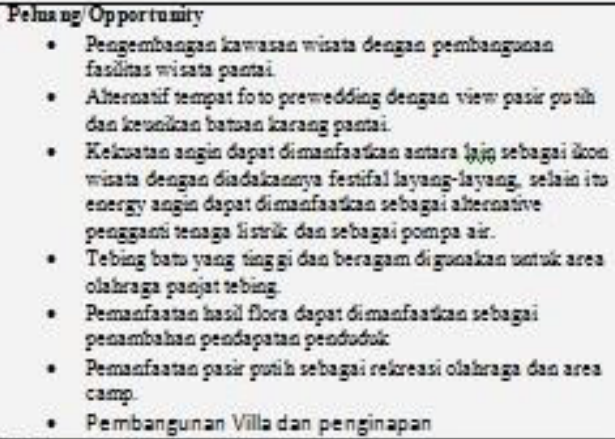 & 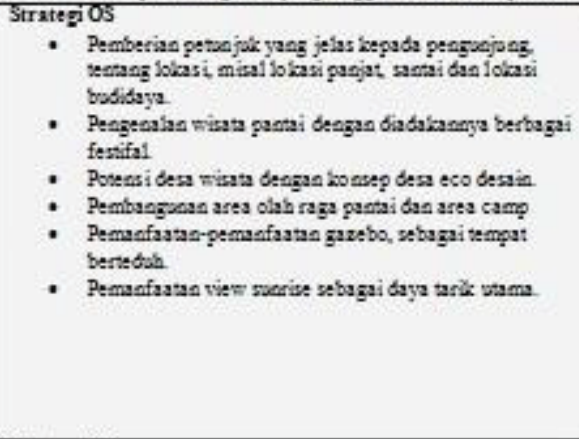 & 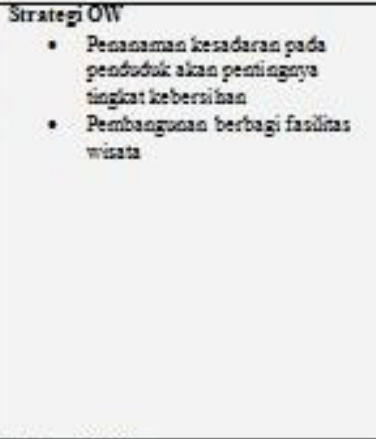 \\
\hline 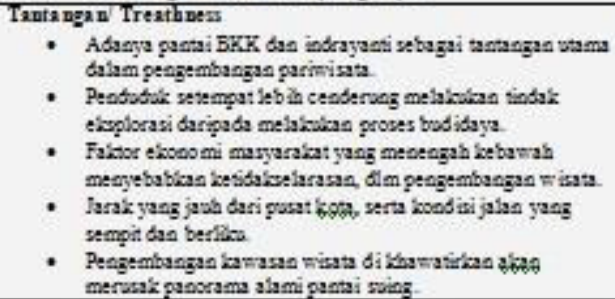 & 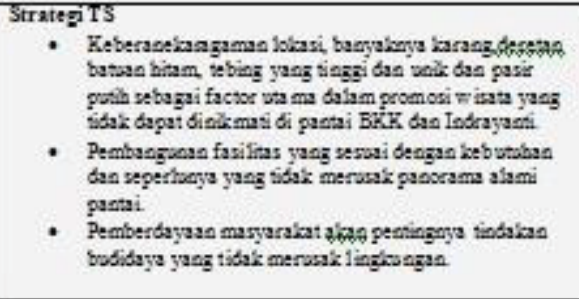 & 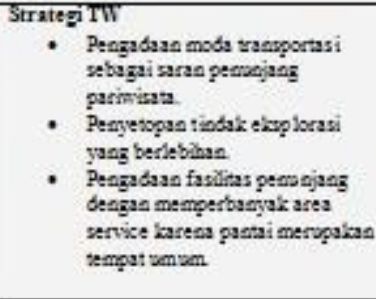 \\
\hline
\end{tabular}

(Sumber: Analisis, 2013)

Analisis EOE (Environmental Opportunity Element)

\begin{tabular}{|c|c|c|c|c|}
\hline No. & EOE & Bobot & Nilai (1-5) & Skor \\
\hline 1. & Land Use & 0.30 & 4 & 1.20 \\
\hline 2. & Posisi Lahan & 0.20 & 5 & 1.00 \\
\hline 3. & Luasan Lahan & 0.20 & 4 & 0.80 \\
\hline 4. & Perkembangan IT & 0.15 & 3 & 0.45 \\
\hline 5. & Pertumbuhan Ekonomi & 0.15 & 2 & 0.30 \\
\hline \multicolumn{2}{|c|}{ Total } & 1.00 & & 3.75 \\
\hline
\end{tabular}

Analisis ETE (Environmental Treat Element)

\begin{tabular}{|c|c|c|c|c|}
\hline No. & ETE & Bobot & Nilai (1-5) & Skor \\
\hline 1. & New Entry & 0.30 & 3 & 0.90 \\
\hline 2. & Kompetitor & 0.25 & 4 & 1.00 \\
\hline 3. & Substitusi & 0.15 & 1 & 0.15 \\
\hline 4. & Regulasi & 0.15 & 2 & 0.30 \\
\hline 5. & Bahan Baku & 0.15 & 3 & 0.45 \\
\hline & Total & 1.00 & & 2.80 \\
\hline
\end{tabular}

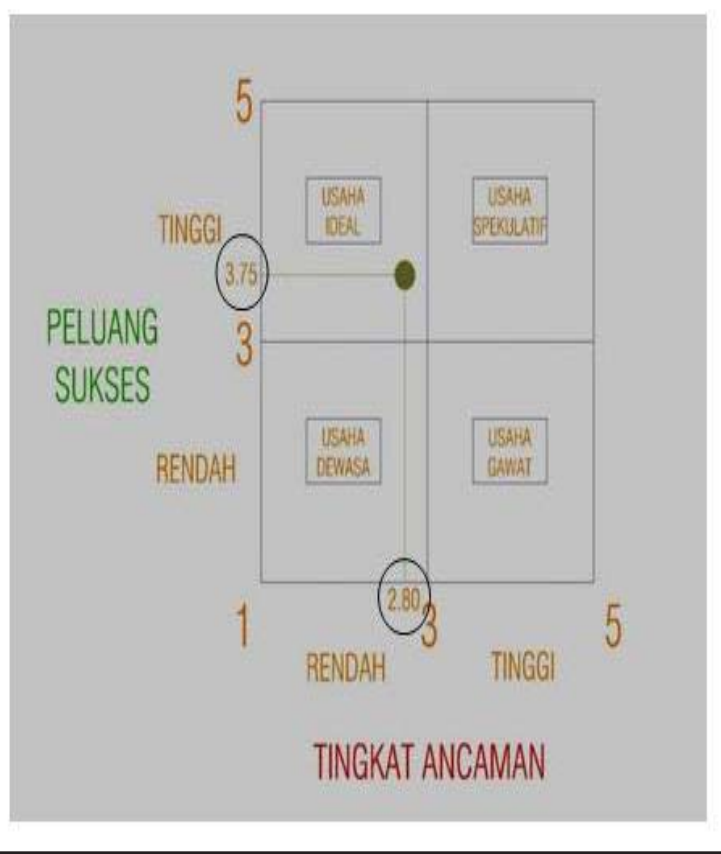

Gambar 5. Hasil Analisis ETOP pada Ketiga Pantai adalah "Usaha Ideal"

(Sumber: Analisis, 2013) 
Tabel 4. Hasil Analisis SAP pada Ketiga Pantai adalah "Posisi Kuat"

\begin{tabular}{|c|c|c|c|c|c|c|c|c|c|}
\hline \multirow{2}{*}{ Faktor kunci sukses } & \multirow{2}{*}{ Bobot } & \multicolumn{7}{|c|}{ Nilai } & \multirow{2}{*}{ NXB } \\
\hline & & -3 & -2 & -1 & 0 & 1 & 2 & 3 & \\
\hline Prasarana & 9.50 & & & & 0 & & & & 0 \\
\hline Sarana & 9.00 & & & & & 1 & & & 9.00 \\
\hline Modal & 8.50 & & & & & 1 & & & 8.50 \\
\hline View & 8.00 & & & & & & 2 & & 16.00 \\
\hline Kondisi Pasir Putih & 7.50 & & & & & & 2 & & 15 \\
\hline Keanekaragaman Karang & 7.00 & & & & & & 2 & & 14.00 \\
\hline Sunset dan Sumrise & 6.50 & & & & 0 & & & & 0 \\
\hline Kondisi Perairan & 6.00 & & & & & & & 3 & 18.00 \\
\hline Ombak dan Arus Laut & 5.50 & & & & & & 2 & & 11.00 \\
\hline Vegetasi & 5.00 & & & & & 1 & & & 5.00 \\
\hline Perahu & 4.50 & & & & 0 & & & & 0 \\
\hline Angin & 4.00 & & & & & & & 3 & 12.00 \\
\hline Teknologi & 3.50 & & & & & 1 & & & 3.50 \\
\hline Ketertiban dan Kebersihan & 3.00 & & & & & & 2 & & 6.00 \\
\hline Nilai Tambah & 2.50 & & & & & & 2 & & 5.00 \\
\hline Pokdarwis & 2.00 & & & & & & & 3 & 6.00 \\
\hline LSM & 1.50 & & & & & & & 3 & 4.50 \\
\hline Total & 93.50 & -280.5 & -187.0 & -93.5 & 0.0 & 93.5 & 187.0 & 280.5 & 133.5 \\
\hline \multicolumn{2}{|l|}{ Posisi Persaingan: } & \multicolumn{3}{|c|}{ Lemah } & Ama & \multicolumn{2}{|c|}{ Kuat } & ggul & \\
\hline
\end{tabular}

(Sumber: Analisis, 2013)

Tabel 5. Hasil Matrik SWOT (Gabungan ETE-EOE dan SAP) adalah "I=Investasi"

\begin{tabular}{|l|c|c|c|c|}
\hline \multicolumn{1}{|c|}{ ETOP } & $\begin{array}{c}\text { Ideal Business } \\
\text { (Usaha Ideal) }\end{array}$ & $\begin{array}{c}\text { Mature Business } \\
\text { (Usaha Dewasa) }\end{array}$ & $\begin{array}{c}\text { Trouble Business } \\
\text { (Usaha Gawat) }\end{array}$ & $\begin{array}{c}\text { Speculatif Business } \\
\text { (Usaha Spekulatif) }\end{array}$ \\
\hline $\begin{array}{l}\text { Dominant Position } \\
\text { (Posisi Unggul) }\end{array}$ & I & I & I & I \\
\hline $\begin{array}{l}\text { Strong Position } \\
\text { (Posisi Kuat) }\end{array}$ & I & I & I & I \\
\hline $\begin{array}{l}\text { Favourable Position } \\
\text { (Posisi Aman) }\end{array}$ & I & I & I & D \\
\hline $\begin{array}{l}\text { Tenable Position } \\
\text { (Posisi Bertahan) }\end{array}$ & I & I & D & D \\
\hline $\begin{array}{l}\text { Weak Position } \\
\text { (Posisi Lemah) }\end{array}$ & & D & D & D \\
\hline
\end{tabular}

Keterangan: I=Investasi dan D=Direstasi

(Sumber: Analisis, 2013) 


\section{KESIMPULAN DAN SARAN}

Kajian SWOT mampu memperlihatkan secara mudah tentang kondisi eksternal (matrik ETOP) dan internal (matrik SAP) suatu entitas. Berdasarkan hasil analisis matrik ETOP, maka ketiga pantai yang dikaji, yaitu Pantai Jogan, Pantai Nglambor dan Pantai Siung mempunyai posisi usaha ideal, sedangkan untuk matrik SAP masing-masing juga mempunyai posisi persaingan kuat. Jadi, melalui analisis matrik SWOT, Pantai Jogan, Pantai Nglambor dan Pantai Siung terbukti cukup aman untuk diadakan kebijakan investasi pengembangan, yaitu sebagai kawasan wisata pantai yang baru. Namun demikian, karena terkait kondisi geografisnya, masing-masing pantai dikembangkan dengan pola yang berbeda-beda. Pantai Jogan mempunyai karakter yang unik, yaitu adanya aliran air yang mengalir dari tebing karang yang langsung jatuh ke bibir pantai, sehingga dikembangkan sebagai pantai air terjun. Pantai Nglambor mempunyai pemandangan yang sangat indah, yaitu adanya hamparan pasir putih, pulau karang dan keragaman ikan hias, sehingga layak dikembangkan sebagai pantai pasir putih. Sementara itu, Pantai Siung mempunyai batuan karang yang unik, tebing yang tinggi dan hamparan pasir putih yang luas, sehingga layak dikembangkan sebagai pantai petualang. Selanjutnya, penelitian ini akhirnya merekomendasikan untuk dilakukan tahap penyusunan konsep perencanaan dan perancangan arsitektur, khususnya desain kawasan pantai.

\section{DAFTAR PUSTAKA}

Bapeda Gunung Kidul, 2011. Peraturan Daerah Kabupaten Gunung Kidul No. 6/ 2011 tentang Rencana Tata Ruang Wilayah (RTRW) Kabupaten Gunung Kidul, Pemkab GunungKidul, Gunung Kidul, DIY.

Dahuri, R., 1996. Pengolahan Sumber Daya Wilayah Pesisir dan Lautan Terpadu, PT. Pradnya Paramitha, Jakarta.

Ginting, P., 2004. Geografi, Erlangga, Jakarta.

Porter, Michael E., 1980. Competive Strategy, Free Press, London.

PP No. 50/2011. Rencana Induk Pengembangan (RIP) KepariwisataanNasional, Sekretariat Negara, Jakarta.

Qomarun, 1997. Analisis Strategi Bisnis Properti pada Era Globalisasi di Indonesia(Study Kasus pada PT Jaya Real Property), Tesis IPWI Jakarta, Jakarta.

UU No. 10/2009. Kepariwisataan, Sekretariat Negara, Jakarta.

Yoeti, Oka, 1985. Pengantar IImu Pariwisata, Angkasa, Jakarta 